\title{
Broad-range and effective detection of human noroviruses by colloidal gold immunochromatographic assay based on the shell domain of the major capsid protein
}

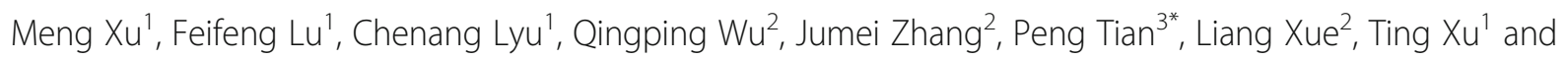
Dapeng Wang ${ }^{1 *}$

\begin{abstract}
Background: Human noroviruses (HuNoVs) are a major cause of nonbacterial gastroenteritis in all age groups worldwide. HuNoVs can be detected in vitro using molecular assays such as RT-PCR and RT-qPCR. However, these molecular-based techniques require special equipment, unique reagents, experienced personnel, and extended time to obtain results. Besides, the diversity of viral genotypes is high. Therefore, methods that are rapid, broadrange and effective in the detection of HuNoVs are desiderated for screening the feces or vomit of infected people during outbreaks.

Results: In this study, a colloidal-gold-based immunochromatographic assay (ICA) was developed for effective detection of HuNoVs in clinical samples. Monoclonal antibodies (MAbs) against the shell (S) domain in the major capsid protein of HuNoVs were used in the ICA. The limitations of detection for HuNoVs in clinical samples were $1.2 \times 10^{6}$ genomic copies per gram of stool sample (gc/g) and $4.4 \times 10^{5} \mathrm{gc} / \mathrm{g}$ for genogroup I and II (GI and GII) HuNoVs, respectively. A total of 122 clinical samples were tested for HuNoVs by ICA and compared against RT-qPCR. The relative sensitivity, specificity and agreement of ICA was 84.2\% (95\% Cl: 83.6-84.8\%), 100.0\% (95\% Cl: 98.5$100.0 \%)$ and $87.7 \%$ (95\% Cl: 85.6-89.8\%), respectively. No cross-reaction with other common enteric viruses or bacteria was observed. The ICA detected a broad range of genotypes, including GI.1, GI.3, Gl.4, Gl.6, Gl.14, GII.2, GIl.3, Gll.4, Gll.6, Gll.13, and Gll.17 HuNoVs.
\end{abstract}

Conclusions: This study demonstrates that ICA targeting the S domain of VP1 is a promising candidate for effectively identifying the different genotypes of HuNoVs in clinical samples with high sensitivity and specificity.

Keywords: Human norovirus, Broad-range detection, S domain of VP1, Colloid gold, Immunochromatographic assays

\footnotetext{
*Correspondence: peng.tian@ars.usda.gov; dapengwang@sjtu.edu.cn

${ }^{3}$ Western Regional Research Center, Agricultural Research Service-United

States Department of Agriculture, Produce Safety and Microbiology Research Unit, Albany, CA 94706, USA

${ }^{1}$ Department of Food Science and Technology, School of Agriculture and Biology, Shanghai Jiao Tong University, Shanghai 200240, China

Full list of author information is available at the end of the article
}

(c) The Author(s). 2021 Open Access This article is licensed under a Creative Commons Attribution 4.0 International License, which permits use, sharing, adaptation, distribution and reproduction in any medium or format, as long as you give appropriate credit to the original author(s) and the source, provide a link to the Creative Commons licence, and indicate if changes were made. The images or other third party material in this article are included in the article's Creative Commons licence, unless indicated otherwise in a credit line to the material. If material is not included in the article's Creative Commons licence and your intended use is not permitted by statutory regulation or exceeds the permitted use, you will need to obtain permission directly from the copyright holder. To view a copy of this licence, visit http://creativecommons.org/licenses/by/4.0/ The Creative Commons Public Domain Dedication waiver (http://creativecommons.org/publicdomain/zero/1.0/) applies to the data made available in this article, unless otherwise stated in a credit line to the data. 


\section{Background}

Human noroviruses (HuNoVs) are single-stranded RNA, non-enveloped viruses in the Caliciviridae family. The genome has three open reading frames (ORFs, 1 through $3)$, where ORF2 encodes a major capsid protein referred to as VP1. VP1 consists of a shell (S) domain and a protruding $(\mathrm{P})$ domain. The $\mathrm{S}$ domain is the most highly conserved region in VP1, and forms a shell surrounding the RNA genome, while the P domain of VP1 contains the most variable sequence [1-3]. HuNoVs are divided into 5 genogroups based on the VP1, including genogroup I (GI), II (GII), IV (GIV), VIII (GVIII), and IX (GIX) [4]. GI and GII HuNoVs are the major epidemic strains circulating worldwide [5].

HuNoVs are the most common causes of epidemic gastroenteritis worldwide [6-8]. The HuNoVs infections cause about 700 million illnesses and over 200 thousand deaths globally every year $[9,10]$. HuNoVs are highlyinfectious, and infected patients can shed high titers of virus particles with strong resistance to environmental factors [11, 12]. The establishment of an efficient in vitro cell culture for $\mathrm{HuNoVs}$ remains challenging [13], therefore, the detection of the virus mainly depends on molecular approaches such as RT-PCR and RT-qPCR $[14,15]$. These molecular approaches require specialized equipment, unique reagents, and significant time for sample preparation and assay execution, which make them impractical for either clinical use or on-site assays of field samples requiring quick results. To efficiently control the spreading of HuNoVs in time, a highly effective, safe, and portable point-of-care testing is of great importance in monitoring and managing the spread of an outbreak.

An immunochromatography assay (ICA) determines the presence or absence of a target analyte, such as pathogens or biomarkers $[16,17]$. A schematic diagram of ICA is shown in Fig. 1. In an ICA test, an antibody against the viral capsid is labeled with gold particles. The labeled antibody captures the viral capsid and another antibody coated on the solid-phase carrier, thus the virus-antibody-colloidal gold particle combinations cause aggregation to occur and cause a color change to red indicating positive results. ICAs do not require any specialized equipment and minimal training is needed to perform the test. Results can be visually displayed within a few minutes. Currently, several ICAs used for the detection of bacterial and viral pathogens have been reported $[18,19]$. However, the limitations of the ICA kits in HuNoVs detection were obvious, such as the specific detection of genotypes and low sensitivity [20]. Therefore, a broad-range and highly effective ICA is needed for point-of-care testing of HuNoVs.
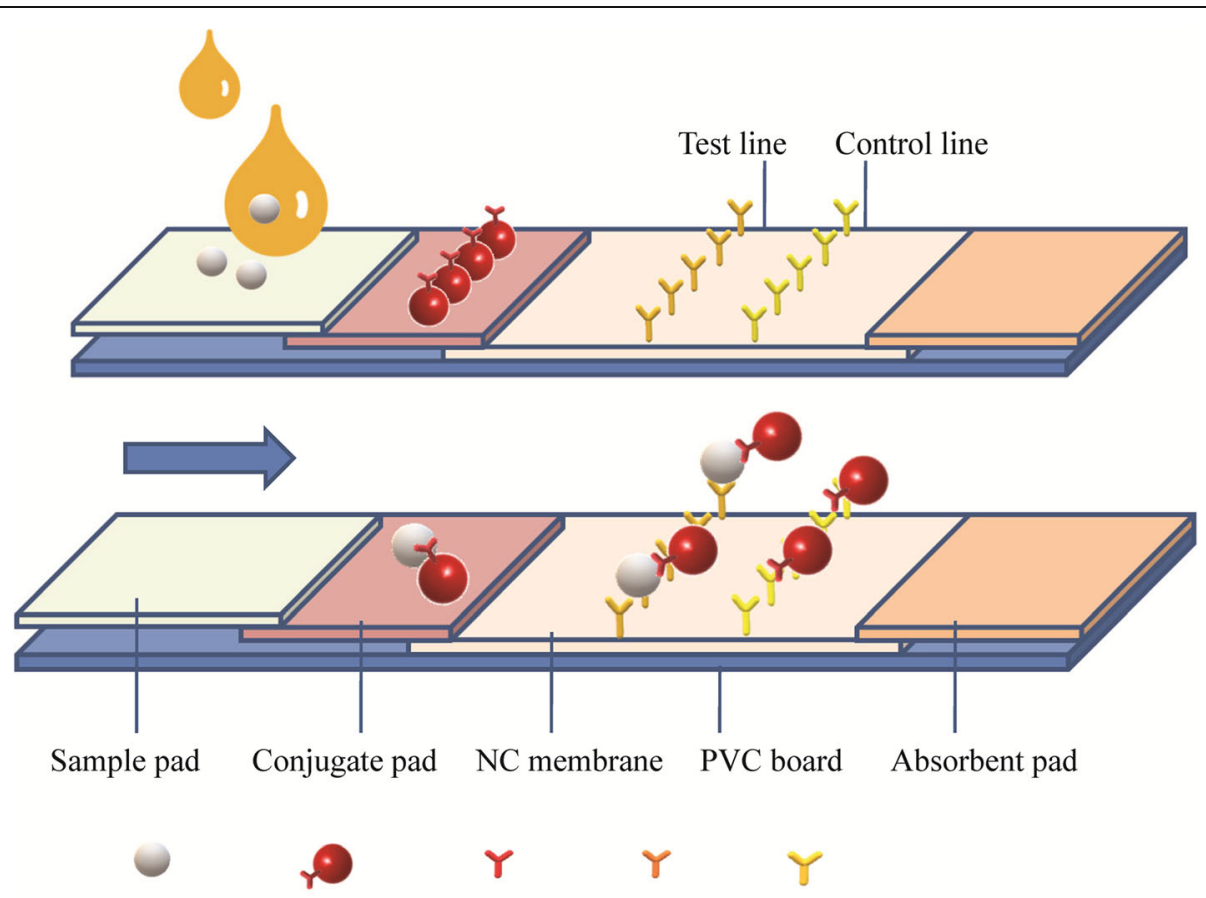

Antigen Gold-probe MAb H9E MAb J5D Goat-anti mouse antibody

Fig. 1 Schematic diagram of ICA test. MAb H9E was used as labeled antibody with colloidal gold particles (in red); MAb J5D was used as captureantibody in the T line; goat-anti mouse MAb Ig G was used in the $C$ line. Arrow indicates the direction of the movement of antigens (capsid protein of noroviruses) 
$\mathrm{Li}$ et al. reported that a MAb against the $\mathrm{S}$ domain of VP1 could cross-react with GI, GII, GIII, and GV of noroviruses (NoVs) [21]. Yoda et al. reported that two MAbs generated against the $\mathrm{S}$ domain of GII HuNoVs capsid protein also recognized the viral protein of GI HuNoVs [22]. Besides, Parra et al. identified a broad cross-reactive epitope in the $\mathrm{S}$ domain of the NoVs capsid [2]. Therefore, the $S$ domain of VP1 is highly conserved and serves as a good candidate for detecting multiple genotypes of HuNoVs. However, few immunoassays have been reported to detect HuNoVs targeting the S domain of VP1. In this study, three MAbs were generated against the $\mathrm{S}$ domain of VP1 from GII.4 $\mathrm{HuNoV}$ and used to develop an ICA for broad and effective detection of both GI and GII HuNoVs.

\section{Results}

Selection of MAbs recognizing different epitopes on the $S$ domain of VP1 for ICA

Selection of MAbs recognizing different epitopes on $\mathrm{S}$ domain of VP1 could enhance the sensitivity and specificity of the assay. Three MAbs were selected and named $\mathrm{H} 9 \mathrm{E}, \mathrm{B} 4 \mathrm{H}$, and $\mathrm{J} 5 \mathrm{D}$, further abbreviated as $\mathrm{H}, \mathrm{B}$, and $\mathrm{J}$, respectively. The values of the displacement factor $(I)$ of B-H, H-B, B-J, J-B, H-J, and J-H combinations determined by ELISA were 32.8, 28.9, 34.1, 29.6, 31.2, and $22.7 \%$, respectively. $I$ value greater than $10.0 \%$ indicated that two MAbs recognized different epitopes on the $S$ domain of VP1. Among the $I$ values of the six pairs, B-J showed the best matching effect. The results were further tested by the ICA assay to find the best combination of MAbs binding to the gold particles (Table 1). Finally, $\mathrm{H}$ was selected as the antibody for the colloid labeled gold, and $\mathrm{J}$ as the test-line capture antibody, which is shown in both the test and control lines.

\section{Pretreatment methods to expose the S domain of VP1 in the clinical samples}

Unlike the P domain of VP1, the S domain of VP1 is hidden inside of the viral capsid. Two methods were used to expose the $\mathrm{S}$ domain of VP1 in clinical samples

Table 1 Results obtained from different combinations of the three antibodies on the colloidal gold platform

\begin{tabular}{lllll}
\hline & Colloidal-gold MAb & Test line MAb & Test line & Control line \\
\hline $\mathrm{BH}:$ & $\mathrm{B} 4 \mathrm{H}$ & $\mathrm{H} 9 \mathrm{E}$ & + & + \\
$\mathrm{HB}:$ & $\mathrm{H} 9 \mathrm{E}$ & $\mathrm{B} 4 \mathrm{H}$ & ++ & + \\
$\mathrm{BJ}:$ & $\mathrm{B} 4 \mathrm{H}$ & $\mathrm{J} 5 \mathrm{D}$ & + & ++ \\
$\mathrm{JB}:$ & J5D & B4H & ++ & + \\
$\mathrm{HJ}:$ & H9E & J5D & ++ & ++ \\
$\mathrm{JH}:$ & J5D & $\mathrm{H} 9 \mathrm{E}$ & + & + \\
\hline
\end{tabular}

" + " represented the color depth. The score was evaluated by multiple operators with hidden labels and to inactivate the virus. By increasing the temperature from $60^{\circ} \mathrm{C}$ to $80^{\circ} \mathrm{C}$, the OD readings gradually increased (roughly from 0.2 to 1.0 ). However, the OD readings dramatically decreased when the temperature was greater than $90^{\circ} \mathrm{C}$ (less than 0.2). A 3 -min treatment at $80^{\circ} \mathrm{C}$ obtained the best heat-treatment results (Fig. S1, see Additional file 1). A progressive improvement in detection was displayed when $\mathrm{pH}$ increased from 7.0 to 9.0 (optimal at $\mathrm{pH}=9.0$, consistent with the best effect of heat treatment) (Fig. S2, see Additional file 1). Alkali treatment performed better than heat-treatment, the OD readings were easy to control and stable over the time tested, and there was no significant difference between the best 10 -min and the worst 5-min treatment $(p=0.131>$ $0.05)$. For simplicity and repeatability of the experiment, alkali treatment (samples were treated to $\mathrm{pH}=$ 9.0 at room temperature for $10 \mathrm{~min}$ ) was used to expose the S domain of VP1 in all clinical samples before ICA testing.

\section{The sensitivity and specificity of ICA}

The sensitivity of ICA is based on the limit of detection (LOD). The LOD of ICA is determined by applying serially diluted HuNoVs on an ICA strip. The results were judged by visualization of both the test line and control line. The $\mathrm{C}_{t}$ data and the copies were recorded as shown in Table S1 (Additional file 2). The visual LOD of the ICA for the determination of the S domain of VP1 was $1.4 \mathrm{ng} / \mathrm{ml}$. The LODs of viral genomic copies of samples 57,404 (GI) and 1717 (GII) were $1.2 \times 10^{6} \mathrm{gc} / \mathrm{g}$ and $4.4 \times$ $10^{5} \mathrm{gc} / \mathrm{g}$, respectively. The sensitivity test was performed in triplicate, and representative results are shown in Fig. 2.

The specificity of ICA was determined using a set of clinical samples with HuNoVs and other pathogens, and compared with RT-qPCR results. When the clinical samples were detected by ICA, only samples containing $\mathrm{HuNoVs}$ showed positive results. Clinical samples containing other enteric viruses (4 Rotaviruses, 3 Sapoviruses, 2 Astroviruses, and 4 Adenoviruses) or bacteria causing gastroenteritis (3 Salmonellas) all tested negative. Parts of the results are shown in Fig. 3. A comparison of the ICA and RT-qPCR results are shown in Table 2. Eighty samples were found to be positive by ICA from 95 RT-qPCR HuNoVs positive samples. The sensitivity was $84.2 \%$ (95\% CI: 83.6-84.8\%) (80/95). There were no false-positive results, indicating a specificity of $100.0 \%$ (95\% CI: $98.5-100.0 \%$ ) (27/27). The overall agreement of ICA and RT-qPCR was $87.7 \%$ (95\% CI: 85.6-89.8\%) (107/122). Besides, the titers of HuNoVs in 15 negative samples (1 GI.6, 1 GII.3, 12 GII.4, and 1 GII.6) are shown in Table S2 (Additional file 2). The viral loads of 15 ICA false-negative samples were below the LOD of ICA. 

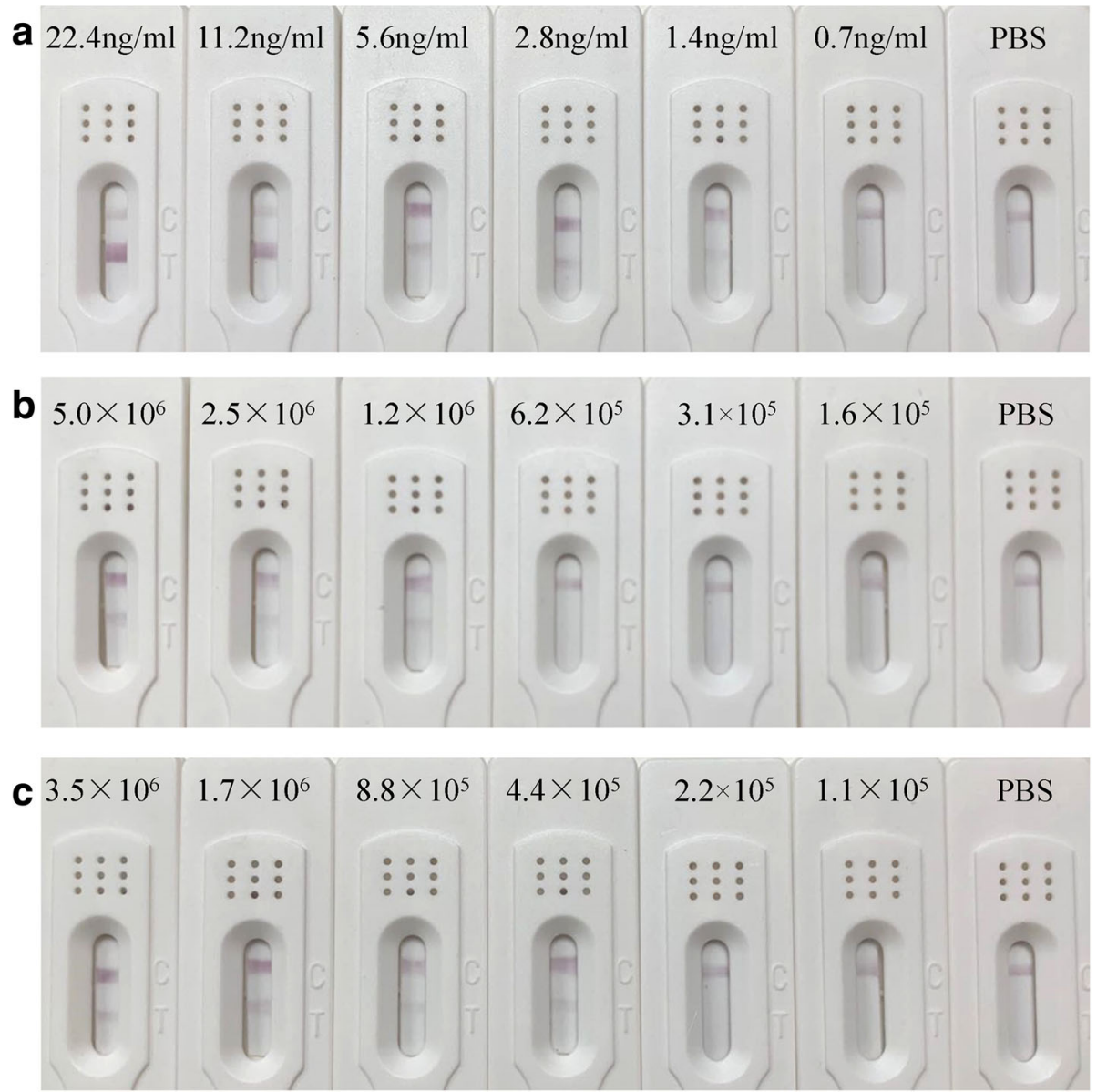

Fig. 2 LOD of ICA for purified S domain of VP1 and clinical samples. a Sensitivity for S domain of VP1 (two-fold dilutions from $22.4 \mathrm{ng} / \mathrm{ml}$ to 0.7 $\mathrm{ng} / \mathrm{ml}$ ), b Sample 57,404 (Gl.1) (two-fold dilutions from $5.0 \times 10^{6}$ to $1.6 \times 10^{5} \mathrm{gc} / \mathrm{g}$ ) and (c) Sample 1717 (Gll.4) of different virus copies (two-fold dilutions from $3.5 \times 10^{6}$ to $1.1 \times 10^{5} \mathrm{gc} / \mathrm{g}$ ) were detected with test strips. PBS buffer ( $\left.\mathrm{pH} 7.4\right)$ was used as blank control

Sequencing results signaled that GII.4 was the dominant genotype (72/95) followed by GI.1 (4/95) in RTqPCR HuNoV-positive samples. Other genotypes were GI.3 (2/95), GI.4 (3/95), GI.6 (2/95), GI.14 (1/95), GII.2 (2/95), GII.3 (3/95), GII.6 (3/95) GII.13 (1/95), and GII.17 (2/95) (Table 3). ICA detected both GI and GII HuNoVs, including GI.1, GI.3, GI.4, GI.6, GI.14, GII.2, GII.3, GII.4, GII.6, GII.13, and GII.17 genotypes. Our
ICA could detect all 11 genotypes. The 15 false-negative samples were because of the low titer.

\section{Stability of ICA strips}

The findings demonstrated that the acceptable activity $(90.0 \%)$ of the initial activity was retained for 21 days when the test strip was exposed to $60^{\circ} \mathrm{C}$. Therefore, we

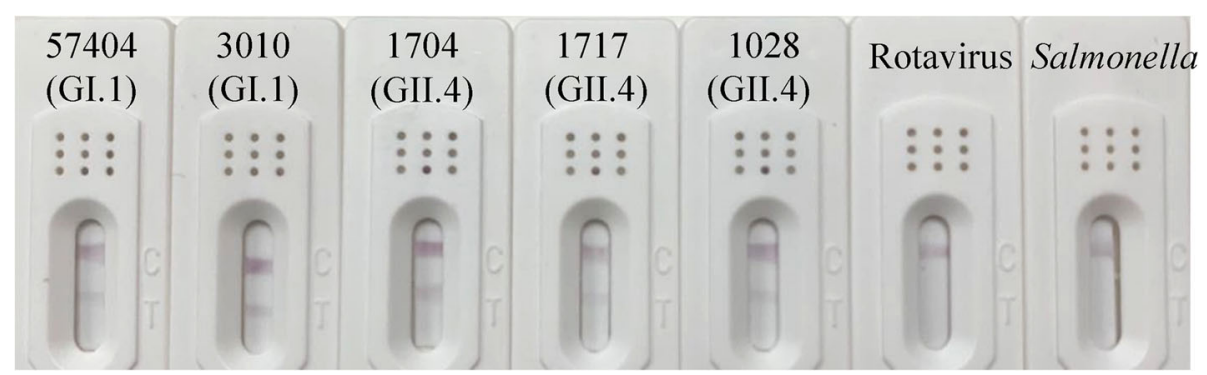

Fig. 3 Specificity of ICA. Five HuNoVs clinical samples, Rotavirus, and Salmonella cultured samples were tested with the strips 
Table 2 A comparison of HuNoVs detection in stool samples between the ICA and the RT-qPCR

\begin{tabular}{lllll}
\hline & & ICA & & \\
\cline { 3 - 5 } & & Positive & Negative & Total \\
\hline RT-qPCR & Positive & 80 & 15 & 95 \\
& Negative & 0 & 27 & 27 \\
& Total & 80 & 42 & 122 \\
\hline
\end{tabular}

hypothesized that the shelf-life of ICA strips remains stable for more than 21 days at room temperature.

\section{Discussion}

HuNoVs are recognized as one of the most important foodborne pathogens worldwide [23]. The burden of HuNoVs outbreaks is high and is reflected in the extensive infectivity and severe economic losses [24]. Acute gastroenteritis outbreaks associated with $\mathrm{HuNoVs}$ are particularly challenging to control because of their stability in the environment and efficient transmission in hospitals, hotels, schools, and homes [25-27]. Therefore, a broad and highly effective assay is needed to rapidly identify HuNoVs and provide emergency treatment during outbreaks.

Fecal specimens from patients could contain up to $10^{9}$ gc/g of HuNoVs [28], risky for the operators. Therefore, the inactivation of the viral particles in clinical samples is crucial before detection. To address this need, physical and chemical treatment methods were evaluated in this study. Our results indicated that the capsid was greatly disassembled following alkaline ( $\mathrm{pH} 9.0$ for $10 \mathrm{~min}$ ) and heat $\left(70.0^{\circ} \mathrm{C}\right.$ for $\left.3 \mathrm{~min}\right)$ treatment. The alkali treatment performed better than the heat treatment in terms of results stability and simplicity. More important, the alkali environment also maintained the colloidal gold in a stable state to bind MAbs.

VP1 proteins (P plus S domains) can self-assemble to form virus-like particles (VLPs) which morphologically and antigenically resemble the viral particles [29, 30]. The protruding (P) domain of VP1 is highly immunogenic and similar to VLP [31]. The antigenicity of VLP and $P$ particles is often strain-specific and not suitable for viral screening. On the other hand, the S domain of VP1 in HuNoVs is highly conserved [7]. Numerous studies have reported that two MAbs (1B4 and 1F6) of the S domain of VP1 against the capsid protein (NoV GII) reacted with NoV GI [22, 32]. In this study, MAbs against the $\mathrm{S}$ domain of VP1 were prepared to develop an ICA kit, which recognized VP1 from either GI or GII HuNoVs. Moreover, the results demonstrated that the kit had good sensitivity and specificity for the detection of both GI and GII HuNoVs (Table 3).

The epitopes on the S domain of VP1 are hidden in the inner layer of the viruses. They cannot be recognized by antibodies against the S domain of VP1 in the intact viral particles. Therefore, it is important to expose the $\mathrm{S}$ domain of VP1 for virus detection. In this ICA assay, the viral particles were disassembled by alkaline treatment to expose the S domain of VP1. It minimized the risk of infection and kept testers much safer than detection without inactivated samples. In addition, each viral particle contains 90 dimers of viral capsid [33]. Theoretically, more copies of S domain of VP1 are exposed to the MAbs after treatment, thus increasing the sensitivity. Since limited research exists on the antigenicity of the $\mathrm{S}$

Table 3 Detection results of HuNoVs genotypes by ICA

\begin{tabular}{|c|c|c|c|c|}
\hline \multirow{2}{*}{$\begin{array}{l}\text { HuNoVs } \\
\text { genotypes }\end{array}$} & \multirow{2}{*}{$\begin{array}{l}\text { Positive number } \\
\text { in RT-qPCR }\end{array}$} & \multicolumn{2}{|c|}{ Number in ICA } & \multirow[t]{2}{*}{ Sensitivity $(95 \% \mathrm{Cl})$} \\
\hline & & Positive & Negative & \\
\hline Gl.1 & 4 & 4 & 0 & \\
\hline Gl.3 & 2 & 2 & 0 & \\
\hline $\mathrm{Gl} .4$ & 3 & 3 & 0 & \\
\hline $\mathrm{Gl} .6$ & 2 & 1 & 1 & \\
\hline Gl.14 & 1 & 1 & 0 & \\
\hline (GI total) & $(12)$ & (11) & (1) & 91.7 \% (88.6-94.8) \\
\hline Gll.2 & 2 & 2 & 0 & \\
\hline Gll.3 & 3 & 2 & 1 & \\
\hline Gll.4 & 72 & 60 & 12 & \\
\hline Gll.6 & 3 & 2 & 1 & \\
\hline Gll.13 & 1 & 1 & 0 & \\
\hline Gll.17 & 2 & 2 & 0 & \\
\hline (GIl total) & $(83)$ & (69) & (14) & $83.1 \%(80.0-86.3)$ \\
\hline Total & 95 & 80 & 15 & \\
\hline
\end{tabular}


domain of VP1, it will be meaningful to identify the epitopes of $\mathrm{S}$ domain in later studies.

The current molecular assays require special equipment, reagents, and experienced personnel. A simple approach with minimal hands-on time is more applicable and requisite as a screening assay. There are several available commercial immunoassays for $\mathrm{HuNoV}$ detection, such as Quick Ex-Norovirus, RIDA ${ }^{\bullet}$ QUICK (N1402), Immuno Search NV kit, NOROTOP+, and SD Bioline Norovirus [34-40]. However, these methods were more effective for single genotype detection. To detect multiple strains of HuNoVs, a couple of MAbs are selected for cross-reactions with various genotypes. A simple approach is urgently needed to detect a broad-range of HuNoVs.

Numerous studies report the use of IAC in the detection of NoVs. IP-NoV kit and the kit developed by Takanashi were mainly used for GII.3 and GII.4 HuNoVs detection [41-43]. Immuno Search NV kit was developed for several genotypes (GI.1, GI.11, GII.2, GII.3, GII.4, GII.5, and GII.6 VLPs), but the limit of detection was not shown [29]. SD Bioline Norovirus could detect GI.3 for GI but not GII.2, GII.6, and GII.16 for GII HuNoVs [31, 32]. Limited genotypes of HuNoVs are detected by most of the reported kits. It is noteworthy that our ICA could detect a much broader range of genotypes (including GI.1, GI.3, GI.4, GI.6, GI.14, GII.2, GII.3, GII.4, GII.6, GII.13 and GII.17) (Table 3).

Compared to RT-qPCR, the sensitivity, specificity and agreement of our ICA were $84.2 \%$ (95\% CI: 83.6-84.8\%), $100.0 \%$ (95\% CI: $98.5-100.0 \%)$ and $87.7 \%$ (95\% CI: $85.6-$ $89.8 \%$ ), respectively (Table 2 ). The overall results were competitive with other commercial kits. The sensitivity (84.2\%) of our ICAs was higher than IP-NoV kit (ranged from 72.7 to $78.9 \%$ ), Quick Ex-Norovirus (54.5\%), RIDA ${ }^{\circ}$ QUICK (from 68.8 to $82.5 \%$ ), Immuno Search NV kit (75.4\%) and NOROTOP+ (51.4\%) (See Table S3, Additional file 3). Besides, Rotavirus, Sapovirus, Astrovirus, Adenovirus, and Salmonella are the most common non-norovirus viral and bacterial pathogens that also cause gastroenteritis in China [44]. None of the 16 specimens tested positive when evaluating specificity in this study. The detection using ICA was dependent on the visualization of both the test and control line. Future studies will seek to improve the proposed ICA assay.

The performance characteristics of the developed ICA kit were dependent on both the tested individual and the HuNoVs titer in the sample. There were several possibilities for false-negative results, including lower viral titer in the tested clinical samples and sensitivity of the MAbs selected. In our study, 15 false-negative samples identified had viral titers below the LOD. In future studies, the LOD of the developed kit should be improved using quantum dot or signal amplification systems. Nevertheless, the ICA targeting the S domain of VP1 is a promising approach for screening HuNoVs in clinical samples, especially during outbreaks.

\section{Conclusions}

In this study, an ICA targeting the S-domain of the HuNoV VP1 for broad-range detection of HuNoVs is developed. This assay reduces the detection time and has a sensitivity of $84.2 \%$ (95\% CI: $83.6-84.8 \%$ ), and a specificity of $100.0 \%$ (95\% CI: $98.5-100.0 \%$ ), which is highly competitive compared with other immunological kits. Besides, no special equipment and reagents are required. Therefore, the proposed assay presents a promising approach for the screening of $\mathrm{HuNoVs}$ from clinical samples in the field.

\section{Methods}

Preparation of VP1s and the S domain of VP1

HuNoV GI.1 and GII.4 ORF2 gene fragments (GenBank Nos. M87661 and KM114291, respectively) were subcloned separately into the pET-28a prokaryotic expression plasmid. HuNoV GI and GII VP1 proteins were expressed from respective recombinant plasmid vectors pET28a-ORF2 GI.1 and GII.4 in Escherichia coli (E. coli) BL21 cells [45].

HuNoV GII.4 ORF2 (GenBank No. KM114291) was used as a template to amplify the nucleic acid fragment of the $\mathrm{S}$ domain. The upstream primer was $5^{\prime}$-GAATTC ATGAAGATGGCGTCGAGTG-3'; the downstream primer was 5' - CTCGAGCTCAACTGTGGGTGGCAC-3'. $E c o$ R I and Xho I restriction sites were appended to the $5^{\prime}$ ends of forward and reverse primers, respectively. After amplification and digestion, the nucleic acid fragment of the $\mathrm{S}$ domain was inserted into a pSmart vector (Frdbio, China) to generate recombinant pSmart-S. The recombinant $\mathrm{S}$ domain of VP1 was induced and expressed, as described in a previous study [46].

\section{Preparation of anti-S domain of VP1 MAbs}

The MAbs against the S domain of VP1 were prepared as described in our previous study [47]. Three MAbs ( $\mathrm{H} 9 \mathrm{E}, \mathrm{B} 4 \mathrm{H}$, and J5D, further abbreviated as $\mathrm{H}, \mathrm{B}$, and J, respectively) were selected for their ability to bind the pSmart-S expression product, but not with $E$. coli residual proteins. The three MAbs also demonstrated specificity against both GI and GII HuNoV VP1, which was confirmed by Western Blot analysis.

Selection of MAbs recognizing different epitopes of the $S$ domain of VP1 by ELISA assay

Each reaction of the ICA assay utilizes a labeled MAb and an immobilized ("capture") MAb. Since the conditions for the labeled MAb $(40 \mu \mathrm{g} / \mathrm{ml})$ and the immobilized Mab $(2.0 \mathrm{mg} / \mathrm{ml})$ were different, all six pair permutations of the three MAbs (B-H, H-B, B-J, J-B, H-J, and J-H) were tested. 
First, the three MAbs (B, H, and J) were two-fold serially diluted and tested for their single epitope saturation concentrations using a recombinant $\mathrm{S}$ domain of VP1 $(100.0 \mu \mathrm{g} /$ well). A concentration one step lower than the concentration with a significant decrease in $\mathrm{OD}_{450}$ value was defined as a single epitope saturation concentration of the MAbs and named $\mathrm{B}_{1}$ (or $\mathrm{H}_{1}, \mathrm{~J}_{1}$ ). The $\mathrm{S}$ domain of VP1 $(100.0 \mu \mathrm{g} /$ well $)$ was coated overnight at $4{ }^{\circ} \mathrm{C}$, and $100.0 \mu \mathrm{l}$ epitope-saturated MAb (e.g., B) was added and incubated at $37^{\circ} \mathrm{C}$ for $1 \mathrm{~h}$. After washing, $100.0 \mu \mathrm{l}$ of saturated MAb (e.g., $\mathrm{H}$ ) in the test pair was incubated under similar conditions. The $\mathrm{OD}_{450}$ was recorded as $\mathrm{BH}_{2}$. The displacement factor $(I)$ was defined as the ratio of the increased effect of cross-reactivity over the separate effect of the second antibody. If $I>10 \%$ [48], this indicated that the recognition sites of the two MAbs were distinct. $I$ values was calculated using the formula $I$ (e.g., $\mathrm{BH})=\left(\mathrm{BH}_{2}-\mathrm{B}_{1}\right) / \mathrm{H}_{1} \times 100 \%$.

\section{Preparation of the colloidal gold-labeled MAbs}

Colloidal gold particles with a mean particle diameter of $25.0 \mathrm{~nm}$ were produced. One hundred $\mathrm{ml}$ of $0.01 \%(\mathrm{w} / \mathrm{v})$ chloroauric acid $\left(\mathrm{HAuCl}_{4}\right)$ (Aladdin, Shanghai, China) was thoroughly boiled for $3 \mathrm{~min}$, and $2.0 \mathrm{ml}$ of $1.0 \%$ (w/ v) sodium citrate (Aladdin, Shanghai, China) quickly added into the solution with magnetic stirring for 30 min. The color gradually changed from yellow to blackblue and finally brilliant red. After stirring for a few minutes at low speed, the colloidal gold suspension could cool down and stored in the dark at room temperature. The total volume was made up to the original volume $(100.0 \mathrm{ml})$ using ultrapure water. To determine the size and distribution of the gold nanoparticles, a transmission electron microscopy (Tecnai G2 spirit Biotwin, USA) was used to scan the colloidal gold solution at 120 KV. The OD value of the colloidal gold solution was measured at 400-680 nm using an ultraviolet spectrophotometer (Tecan Sunrise, Switzerland).

Both physical and chemical crosslinking methods have been used for the conjugation of gold colloids and MAbs [49]. Chemical crosslinking is more stable but the functional groups in MAb are likely to be affected. All the functional domains are retained when MAbs are conjugated by the physical method [50]. In this study, the physical method was used for conjugation [49]. The optimal $\mathrm{pH}$, dose, and BSA concentration during the conjugation of gold colloids and MAbs were evaluated (Fig. S3 and Table S4-6, Additional files 4 and 5). Briefly, $200.0 \mu$ l of a MAb (i.e.H9E) was incubated with $0.5 \mathrm{ml}$ of colloidal gold ( $\mathrm{pH} 9.0$ ) for $30 \mathrm{~min}$ at room temperature and with gentle stirring. Then, $50.0 \mu \mathrm{l} \mathrm{BSA}$ (Amresco, United States) at different concentrations were added into the colloidal gold as a blocking buffer to stabilize the gold-labeled antibody. After $15 \mathrm{~min}$ incubation, centrifugation at $8000 \times \mathrm{g}$ at $4{ }^{\circ} \mathrm{C}$ for $20 \mathrm{~min}$ allowed the collection of the colloidal gold-antibody complex as a pellet, and unbound antibodies were retained in the supernatant. The presence of black massive deposits on the wall of the tube should be avoided during the centrifugal process. The conjugated colloidal gold-antibody was re-suspended in $50.0 \mu \mathrm{l}$ of dissolution buffer (PBS, pH 9.0 containing 10.0\% w/v sucrose (Sangon Biotech, Shanghai, China), 0.2\% (w/v) PVA-205 (Aladdin, Shanghai, China), 0.2\% (v/v) Tween20 (Aladdin, Shanghai, China), and BSA (3.0, 2.5, 2.0, $1.5,1.0$ and $0.5 \%, \mathrm{w} / \mathrm{v})$. The conjugation was confirmed by UV-vis spectroscopy using unlabeled gold particles. A $50.0 \mu \mathrm{l}$ colloidal gold-antibody mixture was evenly dispensed on the $0.5 \mathrm{~cm} \times 2.5 \mathrm{~cm}$ conjugated pad and dried for $3 \mathrm{~h}$ at room temperature.

\section{Selection of MAbs used on the colloidal gold platform}

ICA performance was critically dependent on a combination of the optimal antibody sandwich pair with colloidal gold. ELISA results were considered together with ICA testing. The capture antibody on the Test line ( $T$ line) and the control antibody (goat-anti-mouse Ig G, Beyotime Biotech, Shanghai, China) on the Control line (C line) (Fig. 1) measured $2.0 \mathrm{mg} / \mathrm{ml}$, and the labeled antibody exceeded $40 \mu \mathrm{g} / \mathrm{ml}$. A $0.3 \mu \mathrm{g} / \mathrm{ml}$ of the $\mathrm{S}$ domain of VP1 was used. The final selection was based on a combination of the color effect of both $\mathrm{C}$ and $\mathrm{T}$ lines.

HuNoVs in clinical samples (including suspected HuNoVs) A total of 122 fecal specimens were collected and tested. Five HuNoVs clinical samples [57,404 (GI.1), 3010 (GI.1), 1704 (GII.4), 1717 (GII.4), 1028 (GII.4)] were provided by Dr. Ningbo Liao (Zhejiang Provincial Center for Disease Control and Prevention (CDC)). In total 117 clinical diarrheal samples were provided by the Affiliated Hospital of Guangzhou Medical University (3), the Affiliated Hospital of Sun Yat-sen University (7), Chinese CDC (39), and Anhui Provincial CDC (68). The samples were tested by both RT-qPCR and the developed ICA. Clinical samples provided by Zhejiang Provincial and Chinese CDC were obtained from patients with acute gastroenteritis in 2018. The samples from Anhui provincial CDC and Affiliated Hospital of Guangzhou Medical University were collected in 2017. The samples from the Affiliated Hospital of Sun Yat-sen University were obtained between 2015 and 2017.

\section{Detection of HuNoVs by RT-qPCR and calculation of viral genomic copies}

Real-time RT-PCR was performed using a commercial one-step RT-qPCR kit (Sangon Biotech, China), consisting of $12.5 \mu \mathrm{l} 2 \times$ one-step RT-qPCR Master Mix (with SYBR Green), $0.65 \mu \mathrm{l}$ RT enzyme Mix, and $0.4 \mu \mathrm{l}$ of each 
primer $(0.16 \mu \mathrm{mol} / \mathrm{l})$ (See Table S7, Additional file 6) [51]. The RNA template $(2.0 \mu \mathrm{l})$ and RNase free $\mathrm{ddH}_{2} \mathrm{O}$ were added to make a total volume of $25.0 \mu \mathrm{l}$. The amplification reactions were as follows: reverse transcription at $50{ }^{\circ} \mathrm{C}$ for $30 \mathrm{~min}$; heat-denaturation at $95^{\circ} \mathrm{C}$ for $3 \mathrm{~min}$; 40 cycles with denaturation at $95^{\circ} \mathrm{C}$ for $10 \mathrm{~s}$, annealing and extension at $60{ }^{\circ} \mathrm{C}$ for $30 \mathrm{~s}$. Fluorescence signals were collected at the end of each extension step. The highest dilution from real-time RT-PCR was used to generate a positive cycle threshold $\left(C_{t}\right)$ signal, which was one real-time RT-PCR unit (RT-qPCRU) [14]. Linear standard curves of $C_{t}$ values versus $\log _{10}$ viral genomic copies were generated from a continuous 10-fold dilution (See Fig. S4, Additional file 7). Amplified DNA fragments were sequenced on an ABI 3730XL (Personalbio, China). Automated genotypes were analyzed using a Norovirus Typing Tool Version 2.0 (www.rivm.nl/mpf/ norovirus/typingtool).

\section{Exposure of the S domain of VP1 from viral capsid in clinical samples}

Pretreatment included physical or chemical methods. Heat-denaturation was used for physical treatment. Briefly, $10.0 \%(\mathrm{w} / \mathrm{v})$ fecal sample was diluted with PBS, placed in a water bath at a specific temperature $\left(60{ }^{\circ} \mathrm{C}\right.$, $70{ }^{\circ} \mathrm{C}, 80^{\circ} \mathrm{C}, 90^{\circ} \mathrm{C}, 100{ }^{\circ} \mathrm{C}$ ) for 1 to $5 \mathrm{~min}$ at an interval of $1 \mathrm{~min}$. A reducing agent (DTT) (Thermo Fisher, China) and alkaline conditions were used for chemical treatment. The $\mathrm{pH}$ in PBS was adjusted from 6.0 to 10.0 . The fecal samples were dissolved to $10.0 \%$ with PBS buffers ( $\mathrm{pH}$ 6.0, 7.0, 8.0, 9.0 or 10.0) at room temperature $\left(25^{\circ} \mathrm{C}\right)$ for $5,10,15,20,25$ and $30 \mathrm{~min}$. DTT was added to the homogenized solution of the clinical sample at a final concentration of $1.0 \%$. Sandwich ELISA was used to detect HuNoVs, as previously described [52].

\section{Performing an ICA test}

The procedure used to prepare ICA strips is described in Additional file 8. The sample preparation process was as follows: $10.0 \%(\mathrm{w} / \mathrm{v})$ homogenized solution of stool slurries was prepared with PBS (pH 9.0) (10,000×g, 10 min). DTT was added to a final concentration of $1.0 \%$ and incubated at $25^{\circ} \mathrm{C}$ for $10 \mathrm{~min} .50 \mu \mathrm{l}$ of the mixtures were added to the sample pad. In the presence of adequate amounts of HuNoVs antigens, the binding of the gold-labeled antigen complex occurred at both the $\mathrm{T}$ and $C$ lines. The presence of $C$ line confirmed that the test was valid.

Limit of detection (LOD) of ICA for the purified S domain of VP1 in clinical samples

The purified S domain of the VP1 was used at concentrations of $22.4 \mathrm{ng} / \mathrm{ml}, 11.2 \mathrm{ng} / \mathrm{ml}, 5.6 \mathrm{ng} / \mathrm{ml}, 2.8 \mathrm{ng} / \mathrm{ml}$, $1.4 \mathrm{ng} / \mathrm{ml}$ and $0.7 \mathrm{ng} / \mathrm{ml}$. PBS was used as blank control.
Two HuNoVs positive samples $(57,404$ GI.1 and 1717 GII.4) were two-fold diluted with $1.6 \times 10^{5}$ to $5 \times 10^{6} \mathrm{gc} / \mathrm{g}$ (GI) and $1.1 \times 10^{5}$ to $3.5 \times 10^{6} \mathrm{gc} / \mathrm{g}$ (GII). All experiments were performed in triplicate to confirm the reproducibility of the results.

\section{Evaluating ICA specificity}

To determine the specificity of antibodies in the colloidal gold test, 4 Rotavirus, 3 Sapovirus, 2 Astrovirus and 4 Adenovirus (stool sample provided by Zhejiang CDC, the affiliated Hospital of Guangzhou Medical University and the affiliated Hospital of Sun Yat-sen University) and 3 Salmonella (ATCC 14028, CMCC 50115 and CICC 21482) were tested. The copies of Rotavirus, Sapovirus, Astrovirus, and Adenovirus RNA were more than $10^{7} \mathrm{gc} / \mathrm{g}$ feces.

\section{Stability test}

Thermal acceleration tests were used to determine the stability of the ICA strips, at $60{ }^{\circ} \mathrm{C}$ [53]. The activity of the antibodies on each assay was determined using the lowest detectable S domain of the VP1 concentration $(1.4 \mathrm{ng} / \mathrm{ml})$. The identical strips were tested at appropriate intervals $(1,2,3,7,14,21$, and 28 days). The shelf-life was estimated to be at room temperature.

\section{Statistical analysis}

One-way ANOVA was used for data analysis. SPSSAU, an online data analysis tool, was used to perform all the statistical analyses (www.spssau.com).

\section{Supplementary Information}

The online version contains supplementary material available at https://doi. org/10.1186/s12866-020-02084-z.

Additional file 1: Figure S1. A sandwich ELISA for detecting HuNoVs at diverse processing temperature and time. $(* * 0.01<p<0.05 ; * * * p<$

0.01). Figure S2. A sandwich ELISA analysis of HuNoVs after treatment of $\mathrm{pH}$ at different time. $(* * 0.01<p<0.05 ; * * * p<0.01)$.

Additional file 2: Table S1. The $C_{t}$ data of five stool samples used in the LOD test. Table S2. The Ct data and viral genomic copies of 15 stool samples not detected by ICA.

Additional file 3: Table S3. Commercial kits for sensitivity, specificity and agreement comparison.

Additional file 4: Table S4. Optimal BSA concentration for blocking. Table S5. Selection of conjugate pad and dilution multiple of goldlabeled antibody. Table S6. (A) Selection of the Nitrocellulose Membrane. (B) Optimization of the capture antibody and control antibody concentration. (C) The optimal concentration of sucrose (w/v) for the immobilized antibody on the NC membrane.

Additional file 5: Figure S3. Selection of optimal conditions for goldlabeled antibody complex.

Additional file 6: Table S7. Primers used in RT-qPCR.

Additional file 7: Figure S4. Standard curves for calculation of genomic copies of Gl and Gll HuNoVs.

Additional file 8. Preparation of the sample pad and others and assembling of the ICA. 


\section{Abbreviations}

Cl: Confidence interval; ATCC: American type culture collection; CMCC: National Center for Medical Culture collections; CICC: China Center of Industrial Culture Collection; ELISA: Enzyme-linked immunosorbent assay; DTT: Dithiothreitol

\section{Acknowledgments}

We would extend special thanks to Dr. Ningbo Liao from Zhejiang Provincial CDC, Dr. Miao Jin from Chinese CDC, and Dr. Yong Sun from Anhui Provincial CDC for kindly providing test samples. We also greatly appreciated David Yang (PSMRU, WRRC, ARS, USDA) for his assistance in revising the manuscript and Weicheng Cai (Guangdong Institute of Microbiology) for his complete support of the experiment.

\section{Authors' contributions}

MX: methodology, formal analysis, and writing the original draft. FL: software, investigation, and validation. CL: investigation and validation. QW: methodology and supervision. JZ: project administration and data curation. PT: conceptualization, reviewing, editing, and validation. LX: resources and supervision. CL: resources and visualization. TX: resources and visualization. DW: conceptualization, supervision, and funding acquisition. All authors read and approved the final manuscript.

\section{Funding}

This work was jointly supported by the Ministry of Science and Technology of the People's Republic of China (2017YFC1601200), the National Natural Science Foundation of China (31772078) and the Agri-X Interdisciplinary Fund of Shanghai Jiao Tong University (Agri-X 2017005). The work was also supported by USDA Agricultural Research Service CRIS project (2030-42000050-00D). USDA is an equal opportunity provider and employer.

\section{Availability of data and materials}

The datasets supporting the conclusions of this article are included within the article and its additional files. The datasets used and/or analyzed during the current study are available from the corresponding author on reasonable request.

\section{Ethics approval and consent to participate}

Not applicable.

\section{Consent for publication}

Not applicable.

\section{Competing interests}

The authors declare that they have no conflict of interest.

\section{Author details}

'Department of Food Science and Technology, School of Agriculture and Biology, Shanghai Jiao Tong University, Shanghai 200240, China. ${ }^{2}$ State Key Laboratory of Applied Microbiology Southern China, Guangdong Provincial Key Laboratory of Microbial Culture Collection and Application, Guangdong Open Laboratory of Applied Microbiology, Guangdong Institute of Microbiology, Guangzhou 510070, China. ${ }^{3}$ Western Regional Research Center, Agricultural Research Service-United States Department of Agriculture, Produce Safety and Microbiology Research Unit, Albany, CA 94706, USA

Received: 14 August 2020 Accepted: 29 December 2020

Published online: 11 January 2021

\section{References}

1. Parker TD, Kitamoto N, Tanaka T, Hutson AM, Estes MK. Identification of genogroup I and genogroup || broadly reactive epitopes on the norovirus capsid. J Virol. 2005;79(12):7402-9. https://doi.org/10.1128/JVI.79.12.74027409.2005.

2. Parra Gl, Azure J, Fischer R, Bok K, Sandoval-Jaime C, Sosnovtsev SV, Sande $P$, Green KY. Identification of a broadly cross-reactive epitope in the inner shell of the Norovirus capsid. PLoS One. 2013;8(6):e67592. https://doi.org/10. 1371/journal.pone.0067592.

3. Parra Gl, Sosnovtsev SV, Abente EJ, Sandoval-Jaime C, Bok K, Dolan MA Green KY. Mapping and modeling of a strain-specific epitope in the
Norwalk virus capsid inner shell. Virology. 2016;492:232-41. https://doi.org/ 10.1016/j.virol.2016.02.019

4. Chhabra P, de Graaf M, Parra Gl, Chan MC, Green K, Martella V, Wang Q, White PA, Katayama K, Vennema H, Koopmans MPG, Vinjé J. Updated classification of norovirus genogroups and genotypes. J Gen Virol. 2019; 100(10):1393-406. https://doi.org/10.1099/jgv.0.001318.

5. Motoya T, Nagasawa K, Matsushima $Y$, Nagata N, Ryo A, Sekizuka T, Yamashita A, Kuroda M, Morita Y, Suzuki Y, Sasaki N, Katayama K, Kimura H. Molecular evolution of the VP1 gene in human norovirus Gll. 4 variants in 1974-2015. Front Microbiol. 2017;8:2399. https://doi.org/10. 3389/fmicb.2017.02399.

6. Glass RI, Parashar UD, Estes MK. Norovirus gastroenteritis. N Engl J Med. 2009;361(18):1776-85. https://doi.org/10.1056/NEJMra0804575.

7. Kabue JP, Meader E, Hunter PR, Potgieter N. Human norovirus prevalence in Africa: a review of studies from 1990 to 2013. Trop Med Int Health. 2016; 21(1):2-17. https://doi.org/10.1111/tmi.12617.

8. Kowalzik F, Binder H, Zöller D, Riera-Montes M, Clemens R, Verstraeten T, Zepp F. Norovirus gastroenteritis among hospitalized patients, Germany, 2007-2012. Emerg Infect Dis. 2018;24(11):2021-8. https://doi.org/10.3201/ eid2411.170820

9. Pires S, Fischer-Walker C, Lanata C, Devleesschauwer B, Hall A, Kirk M, Duarte A, Black R, Angulo F. Aetiology-specific estimates of the global and regional incidence and mortality of diarrhoeal diseases commonly transmitted through food. PLoS One. 2015;10(12):e0142927. https://doi.org/10.1371/ journal.pone.0142927.

10. Bartsch S, Lopman B, Ozawa S, Hall A, Lee B. Global economic burden of norovirus gastroenteritis. PLoS One. 2016;11(4):e0151219. https://doi.org/10. 1371/journal.pone.0151219.

11. de Graaf M, van Beek J, Koopmans MP. Human norovirus transmission and evolution in a changing world. Nat Rev Microbiol. 2016;14(7):421-33. https://doi.org/10.1038/nrmicro.2016.48

12. Teunis PF, Moe CL, Liu P, Miller SE, Lindesmith L, Baric RS, Le Pendu J, Calderon RL. Norwalk virus: how infectious is it? J Med Virol. 2008;80(8); 1468-76. https://doi.org/10.1002/jmv.21237.

13. Costantini V, Morantz EK, Browne H, Ettayebi K, Zeng XL, Atmar RL, Estes MK, Vinjé J. Human norovirus replication in human intestinal enteroids as model to evaluate virus inactivation. Emerg Infect Dis. 2018;24(8):1453-64. https://doi.org/10.3201/eid2408.180126.

14. Radin D, D'Souza DH. Simple and rapid detection of Human norovirus from produce using SYBR Green I-based real-time RT-PCR. Food Environ Virol. 2011;3:121-9. https://doi.org/10.1007/s12560-011-9066-5.

15. Zhou Z, Tian Z, Li Q, Tian P, Wu Q, Wang D, Shi X. In situ capture RTGPCR: A new simple and sensitive method to detect human norovirus in oysters. Front Microbiol. 2017:8:554. https://doi.org/10.3389/fmicb. 2017.00554

16. Nakayama T, Zhao J, Takeuchi D, Kerdsin A, Chiranairadul P, Areeratana P, Loetthong P, Pienpringam A, Akeda Y, Oishi K. Colloidal gold-based immunochromatographic strip test compromising optimised combinations of anti-S. suis capsular polysaccharide polyclonal antibodies for detection of Streptococcus suis. Biosens Bioelectron. 2014;60:175-9. https://doi.org/10. 1016/j.bios.2014.03.074

17. Yu G, Yu X, Yang G, Tang Y, Diao Y. A novel diagnostic method to detect Duck Tembusu virus: a colloidal gold-based immunochromatographic assay. Front Microbiol. 2018;9:1001. https://doi.org/10.3389/fmicb.2018.01001.

18. Huang SH, Wei HC, Lee YC. One-step immunochromatographic assay for the detection of Staphylococcus aureus. Food Control. 2007;18(8):893-7. https://doi.org/10.1016/j.foodcont.2006.05.005.

19. Souza IO, Schaer RE, Lima d M, FW RJT, Sousa TJ, Silva AA, Sardi SI, Meyer R, Portela RW. Validation of an immunochromatographic assay for the multiple detection of specific antibodies against HIV, HBV, and HCV. Clin Vaccine Immunol. 2013;20(1):128. https://doi.org/10.1128/CVI.00485-12.

20. Kirby A, Gurgel RQ, Dove W, Vieira SC, Cunliffe NA, Cuevas LE. An evaluation of the RIDASCREEN and IDEIA enzyme immunoassays and the RIDAQUICK immunochromatographic test for the detection of norovirus in faecal specimens. J Clin Virol. 2010;49(4):254-7. https://doi. org/10.1016/j.jcv.2010.08.004.

21. Li X, Zhou R, Tian X, Li H, Zhou Z. Characterization of a cross-reactive monoclonal antibody against Norovirus genogroups I, II, III and V. Virus Res. 2010;151(2):142-7. https://doi.org/10.1016/j.virusres.2010.04.005.

22. Yoda T, Suzuki Y, Terano Y, Yamazaki K, Sakon N, Kuzuguchi T, Oda H, Tsukamoto T. Precise characterization of norovirus (Norwalk-like virus)- 
specific monoclonal antibodies with broad reactivity. J Clin Microbiol. 2003; 41(6):2367-71. https://doi.org/10.1128/jcm.41.6.2367-2371.2003.

23. Dewey-Mattia D, Manikonda K, Hall AJ, Wise ME, Crowe SJ. Surveillance for foodborne disease outbreaks - United States, 2009-2015. MMWR Surveill Summ. 2018;67(10):1-11. https://doi.org/10.15585/mmwr.ss6710a1.

24. Verstraeten T, Cattaert T, Harris J, Lopman B, Tam CC, Ferreira G. Estimating the burden of medically attended Norovirus gastroenteritis: modeling linked primary care and hospitalization datasets. J Infect Dis. 2017;216(8):957-65. https://doi.org/10.1093/infdis/jix410.

25. Wikswo ME, Hall AJ. Outbreaks of acute gastroenteritis transmitted by person-to-person contact--United States, 2009-2010. MMWR Surveill Summ. 2012;61(9):1-12. https://doi.org/10.2105/AJPH.2014.10411e13.

26. Atmar RL, Opekun AR, Gilger MA, Estes MK, Crawford SE, Neill FH, Graham DY. Norwalk virus shedding after experimental human infection. Emerg Infect Dis. 2008;14(10):1553-7. https://doi.org/10.3201/eid1410.080117.

27. Johnston CP, Qiu H, Ticehurst JR, Dickson C, Rosenbaum P, Lawson P, Stokes AB, Lowenstein CJ, Kaminsky M, Cosgrove SE, Green KY, Perl TM. Outbreak management and implications of a nosocomial norovirus outbreak. Clin Infect Dis. 2007:45(5):534-40. https://doi.org/10.1086/520666.

28. Geginat G, Kaiser D, Schrempf S. Evaluation of third-generation ELISA and a rapid immunochromatographic assay for the detection of norovirus infection in fecal samples from inpatients of a German tertiary care hospital. Eur J Clin Microbiol Infect Dis. 2012;31(5):733-7. https://doi.org/10.1007/ s10096-011-1366-z.

29. Tan $M$, Hegde RS, Jiang $X$. The $P$ domain of norovirus capsid protein forms dimer and binds to histo-blood group antigen receptors. J Virol. 2004; 78(12):6233-42. https://doi.org/10.1128/JVI.78.12.6233-6242.2004.

30. Jiang X, Wang M, Graham DY, Estes MK. Expression, self-assembly, and antigenicity of the Norwalk virus capsid protein. J Virol. 1992;66(11):6527-32. https://doi.org/10.0000/PMID1328679.

31. Tan $M$, Jiang $X$. Norovirus $P$ particle: a subviral nanoparticle for vaccine development against norovirus, rotavirus and influenza virus. Nanomedicine (Lond). 2012;7(6):889-97. https://doi.org/10.2217/nnm.12.62.

32. Yoda T, Terano Y, Shimada A, Suzuki Y, Yamazaki K, Sakon N, Oishi I, Utagawa ET, Okuno Y, Shibata T. Expression of recombinant Norwalk-like virus capsid proteins using a bacterial system and the development of its immunologic detection. J Med Virol. 2000;60(4):475-81. https://doi.org/10. 1002/(SICI) 1096-9071(200004)60:4<475::AID-JMV17>3.0.CO;2-B.

33. Buckow R, Isbarn S, Knorr D, Heinz V, Lehmacher A. Predictive model for inactivation of feline calicivirus, a norovirus surrogate, by heat and high hydrostatic pressure. Appl Environ Microbiol. 2008;74(4):1030-8. https://doi. org/10.1128/AEM.01784-07.

34. Mutoh K, Hakamata A, Yagi H, Kurokawa K, Miki N, Kurita I. Evaluation of new commercial immunochromatography kit for norovirus in feces. Pediatr Int. 2009;51(1):164-6. https://doi.org/10.1111/j.1442-200X.2008.02788.X.

35. Bruggink LD, Dunbar NL, Marshall JA. Evaluation of the updated RIDA ${ }^{\oplus}$ QUICK (Version N1402) immunochromatographic assay for the detection of norovirus in clinical specimens. J Virol Methods. 2015;223:82-7. https://doi.org/10.1016/j.jviromet.2015.07.019.

36. Khamrin P, Takanashi S, Chan-It W, Kobayashi M, Nishimura S, Katsumata N, Okitsu S, Maneekarn N, Nishio O, Ushijima H. Immunochromatography test for rapid detection of norovirus in fecal specimens. J Virol Methods. 2009; 157(2):219-22. https://doi.org/10.1016/j.jviromet.2008.12.012.

37. Ambert-Balay K, Pothier P. Evaluation of 4 immunochromatographic tests for rapid detection of norovirus in faecal samples. J Clin Virol. 2013;56(3): 194-8. https://doi.org/10.1016/j.jcv.2012.11.001

38. Kim HS, Hyun J, Kim JS, Song W, Kang HJ, Lee KM. Evaluation of the SD Bioline Norovirus rapid immunochromatography test using fecal specimens from Korean gastroenteritis patients. J Virol Methods. 2012;186(1-2):94-8. https://doi.org/10.1016/j.jviromet.2012.08.014.

39. Park KS, Baek KA, Kim DU, Kwon KS, Bing SH, Park JS, Nam HS, Lee SH, Choi YJ. Evaluation of a new immunochromatographic assay kit for the rapid detection of norovirus in fecal specimens. Ann Lab Med. 2012;32(1):79-81. https://doi.org/10.3343/alm.2012.32.1.79.

40. Prasad BV, Hardy ME, Dokland T, Bella J, Rossmann MG, Estes MK. X-ray crystallographic structure of the Norwalk virus capsid. Science. 1999; 286(5438):287-90. https://doi.org/10.1126/science.286.5438.287.

41. Nguyen TA, Khamrin P, Takanashi S, Le Hoang P, Pham le D, Hoang KT, Satou K, Masuoka Y, Okitsu S, Ushijima H. Evaluation of immunochromatography tests for detection of rotavirus and norovirus among Vietnamese children with acute gastroenteritis and the emergence of a novel norovirus Gll.4 variant. J Trop Pediatr. 2007;53(4):264-9. https:// doi.org/10.1093/tropej/fmm021.

42. Thongprachum A, Khamrin P, Chaimongkol N, Malasao R, Okitsu S, Mizuguchi M, Maneekarn N, Ushijima H. Evaluation of an immunochromatography method for rapid detection of noroviruses in clinical specimens in Thailand. J Med Virol. 2010;82(12):2106-9. https://doi. org/10.1002/jmv.21916.

43. Takanashi S, Okame M, Shiota T, Takagi M, Yagyu F, Tung PG, Nishimura S, Katsumata N, Igarashi T, Okitsu S, Ushijima H. Development of a rapid immunochromatographic test for noroviruses genogroups I and II. J Virol Methods. 2008;148:1-2):1-8. https://doi.org/10.1016/j.jviromet.2007.10.010.

44. Xue Y, Pan H, Hu J, Wu H, Li J, Xiao W, Zhang X, Yuan Z, Wu F. Epidemiology of norovirus infections among diarrhea outpatients in a diarrhea surveillance system in Shanghai, China: a cross-sectional study. BMC Infect Dis. 2015:15:183. https://doi.org/10.1186/s12879-015-0922-z.

45. Niu M, Yu Q, Tian P, Gao Z, Wang D, Shi X. Engineering bacterial surface displayed Human norovirus capsid proteins: a novel system to explore interaction between Norovirus and ligands. Front Microbiol. 2015;6:1448. https://doi.org/10.3389/fmicb.2015.01448.

46. Xu Q, Ni P, Liu D, Yin Y, Li Q, Zhang J, Wu Q, Tian P, Shi X, Wang D. A bacterial surface display system expressing cleavable capsid proteins of Human norovirus: a novel system to discover candidate receptors. Front Microbiol. 2017;8:2405. https://doi.org/10.3389/fmicb.2017.02405.

47. Wang D, Wu Q, Kou X, Yao L, Zhang J. Distribution of norovirus in oyster tissues. J Appl Microbiol. 2008;105(6):1966-72. https://doi.org/10.1111/j.13652672.2008.03970.x

48. Xu Y, van Huystee R. Identification of an antigenic determinant on anionic peanut peroxidase by monoclonal antibodies. J Exp Bot. 1991;42(7):935-45. https://doi.org/10.1093/jxb/42.7.935.

49. Jazayeri M, Amani H, Pourfatollah A, Pazoki-Toroudi H, Sedighimoghaddam B. Various methods of gold nanoparticles (GNPs) conjugation to antibodies. Sens Biosensing Res. 2016;9:17-22. https://doi.org/10.1016/j.sbsr.2016.04.002.

50. Oliver C, Jamur MC. Immunocytochemical methods and protocols. Third edition. Humana press; 2010

51. Kageyama T, Kojima S, Shinohara M, Uchida K, Fukushi S, Hoshino FB, Takeda N, Katayama K. Broadly reactive and highly sensitive assay for Norwalk-like viruses based on real-time quantitative reverse transcriptionPCR. J Clin Microbiol. 2003;41(4):1548-57. https://doi.org/10.1128/jcm.41.4. 1548-1557.2003.

52. Yoda T, Terano Y, Suzuki Y, Yamazaki K, Oishi I, Kuzuguchi T, Kawamoto H, Utagawa E, Takino K, Oda H, Shibata T. Characterization of Norwalk virus Gl specific monoclonal antibodies generated against Escherichia coli expressed capsid protein and the reactivity of two broadly reactive monoclonal antibodies generated against GIl capsid towards GI recombinant fragments. BMC Microbiol. 2001;1:24. https://doi.org/10.1186/1471-2180-1-24.

53. Paek SH, Lee SH, Cho JH, Kim YS. Development of Rapid One-Step Immunochromatographic Assay. Methods. 2000;22(1):53-60. https://doi.org/ 10.1006/meth.2000.1036

\section{Publisher's Note}

Springer Nature remains neutral with regard to jurisdictional claims in published maps and institutional affiliations.

Ready to submit your research? Choose BMC and benefit from:

- fast, convenient online submission

- thorough peer review by experienced researchers in your field

- rapid publication on acceptance

- support for research data, including large and complex data types

- gold Open Access which fosters wider collaboration and increased citations

- maximum visibility for your research: over $100 \mathrm{M}$ website views per year

At $\mathrm{BMC}$, research is always in progress.

Learn more biomedcentral.com/submissions 